PART I

The Legal Making of Res Sacrae 

THE GOAL OF PART I IS TO TELL THE STORY of how legal practitioners conceived of ecclesial property as "sacred things." I take juristic pedagogical texts as the starting point by which and the context in which to interpret all other regulatory evidence. Chapters 1 and 2 form a tightly knit pair: pedagogical texts defined res sacrae (chapter 1) and detailed one of the corollaries of the definition (chapter 2): that res sacrae are protected places. To our knowledge, no extant pedagogical texts support a second corollary, but, as chapter 3 shows, bishops regularly petitioned for one to be added. Bishops requested legal regulation of churches as protecting places. Emperors did, to a limited extent, acknowledge this second corollary. In other words, as the legal concept of res sacrae was applied to Christian temples, it expanded in scope to include churches as protecting places. Part II shows that this was the most contested aspect of the legal regulation of ecclesial property as far as some bishops were concerned. Legally, the protecting capacity of churches was an extension of their protected nature, but bishops preached the opposite in ritual contexts, such as in addresses to clergy, homilies, and hagiographical texts. 



\section{Res Sacrae}

It was an affront to Constantius II in the 350 s to learn that Athanasius of Alexandria celebrated Easter in the Great Church, known as the Caesareum. How dare Athanasius consecrate the Great Church without the permission of the pontifex maximus? ${ }^{1}$ Athanasius, in defense, argued that his use of the Great Church did not amount to its consecration by pointing out precedent in other regions where celebrations of the eucharist took place before the church was officially consecrated. Athanasius instead called his celebration of the eucharist an advanced purification of the place: "The place is ready [for consecration], having already been purified by the prayers which have been offered in it, and requires only the presence of your Piety." ${ }^{2}$ Athanasius did not deny the holiness of the eucharist, but at the same time he acknowledged that it is not the eucharist alone that legally consecrates a church.

Jurists and bishops in the Roman Empire were the ones who made, identified, and controlled "sacred things" (res sacrae). Jurists' writings (especially laws) and bishops' decisions that were codified into ecclesiastical laws (called "canons") supply evidence for their regulatory practices. Laws and canons restricted the process by which a thing could become sacred and which things could be legally recognized as sacred. The present chapter analyzes how the regulatory discourse of the Roman Empire conceived of res sacrae, produced them, constructed an administrative body to manage them, and furthermore how it divested "heretics" of their res sacrae.

Classical Roman jurists conceived of sacred things in the context of an empire that initially did not consider Christian practices licit. Nonetheless, they established legal categories and legal precedent that would come to regulate the production of Christian res sacrae in the fourth century from the time of the emperor Constantine. ${ }^{3}$ Jurists and bishops alike applied to ecclesial property definitions that had been created for "pagan" temples and associated property. As a result, imperial governance controlled which things were Christian res sacrae as well as which Christian administrators could be entrusted with them. Often it was at the 
request of Christian administrators that imperial authorities extended the arm of governmental control. Ecclesiastical administrators likewise had an apparatus of methods for controlling res sacrae, albeit of a different nature. Ecclesiastical administrators could control a person's ecclesiastical status and, as a result, they could impose ecclesiastical discipline, even excommunication, against those who violated their regulations.

Imperial authorities enforced laws, while ecclesiastical authorities enforced canons. Still, the two regulatory bodies did not act separately from one another. Emperors convoked some episcopal synods, sent officials to oversee or even preside over proceedings, ${ }^{4}$ and enforced certain canons by issuing corresponding laws. Bishops petitioned emperors for legislation that supported ecclesiastical practices. Once Constantine recognized the episcopal tribunal (episcopalis audientia), bishops could serve as judges over legal cases, their judgments were considered legally binding, and their sentences could be enforced by imperial authorities. ${ }^{5}$

In their capacity as law- and canon-making authorities, jurists and bishops restricted the production, administration, and use of Christian res sacrae, particularly those founded on private estates. The rules that they promulgated were never created in a vacuum but were composed and enforced in response to specific problems. Sources rarely retain the detailed circumstances that led to the deliberation of canons and laws, but episcopal letters offer a window into the sorts of conflicts that arose over res sacrae. For instance, Synesius of Cyrene, when he was bishop of Ptolemais in the early fifth century, heard a dispute between two bishops over one church and sent a report of the hearings to Theophilus of Alexandria. Synesius's epistolary report details to Theophilus the circumstances under which the dispute arose and how Synesius temporarily resolved it. Synesius had to address the problem of an improper production of a sacred thing. He faced the following questions: Was the place still a "sacred thing" despite the ecclesiastical administrator's improper method of production? How should the ecclesiastical administrator be disciplined for his misconduct? Synesius's letter offers a concrete example of how one bishop responded to a situation that did not conform to legal and canonical conceptions of how res sacrae ought to be produced.

There was no legal or canonical way to deconsecrate a temple or unmake a sacred thing in the Roman Empire. In fact, res sacrae were unowned, so there was not even a designated legal proprietor who could desacralize the property. In effect, this left the legal decision-making about what counts as res sacrae and which bishops may administrate them in the hands of the highest authority: the emperor. Emperors did delegitimize the perceived sacrality of places by outlawing certain cultic practices and confiscating places where such "forbidden practices" occurred. Emperors legally divested others of their sacred things by renaming them, seizing them, giving them to imperially sanctioned administrators, and imposing debilitating penalties on nonimperially sanctioned administrators. Bishops could request of the emperor that confiscatory laws be written against 
their rivals. For example, at the turn of the fifth-century, bishops of North Africa petitioned imperial officials to confiscate the ecclesial property of those bishops they considered illegitimate. The writings of Augustine of Hippo offer glimpses into an effective petition against Crispinus of Calama. Other writings, such as Victor of Vita's History of the Vandal Persecution and Justinian's laws, show how the stigma of the penalty levied against Crispinus and other "heretic" bishops became a century-long sticking point in North Africa's religious milieus.

\section{THE GEOGRAPHICAL AND CHRONOLOGICAL SCOPE OF THE CANONS AND LAWS}

Though I cite canons and laws produced from Constantine's accession through Justinian's tenure, I do not limit the geographical scope to the regions that they and all intervening emperors controlled. Instead, I include regions that continued to rely on classical Roman juristic pedagogy even after they no longer belonged to the Roman Empire, such as Gaul.

The sum total of canons and laws are but a small fraction of the conciliar and legislative decisions that were produced during the period between Constantine and Justinian. As Ramsay MacMullen estimates, probably no less than fifteen thousand councils were convened between $\mathrm{AD} 253$ and 550, but information about only 255 of them has been transmitted to us. ${ }^{6}$ No generalizations can be extrapolated from less than 2 percent of the data. For this reason, the account of rules that follows prefers specificity and nuance over generalization, at the cost of rapidly shifting from one time and place to another.

I examine only the laws that have been transmitted in strictly legal literature (as opposed to reports of laws in, for example, historiographies): the Codex of Theodosius, the Sirmondian Constitutions, the Codex of Justinian, and the Novels and Edicts of Justinian. ${ }^{7}$ Although these compilations were made at specific times and places, they include prescriptions drafted for various regions both East and West. The date of each compilation's collocation is important to note, since it is from that date onward that rules originally made for specific locales became generalized and normalized for empire-wide application.

The Theodosian Codex ${ }^{8}$ was the third of four major efforts to edit and compile imperial constitutions. ${ }^{9}$ It was published in 438 and made a standard for both eastern and western parts of the empire, regardless of the original addressees of the constitutions cited. Conflicting decisions were juxtaposed and the most recent ones made normative. The last book of the codex was devoted entirely to ecclesiastical matters, though mention of ecclesial property is also made in the previous books as well. ${ }^{10}$

The name Sirmondian Constitutions is given to a small collection of eighteen constitutions issued between 333 and 425, and probably compiled by a private collector. In a number of cases, they reproduce in more complete form constitutions 
edited and excerpted in the Theodosian Codex. In such cases, the Sirmondian Constitutions allow one to read portions of constitutions that were edited out by the compilers of the Theodosian Codex. ${ }^{11}$

The Codex of Justinian, published in two editions, also collects imperial constitutions like the Codex of Theodosius II, but it differs from the latter in a number of important respects. For one thing, the book on ecclesiastical legislation did not close the codex but rather opened it as book one. For another, the compilers took a further step in the attempt to render the compilation a standard: they edited out discrepancies and conflicting decisions. The first edition, no longer extant, was published on April 7, 529. The second, updated edition superseded the first and was published five years later on November 16,534 . It is the version by which the Codex of Justinian is known today. ${ }^{12}$

Justinian's legislation issued after the codification project is known collectively as the Novels, and it consists of novels (new laws) and edicts (general laws). ${ }^{13}$ Like the Sirmondian Constitutions, Justinian's novels and edicts were probably collected privately and, for the most part, they transmit complete laws not excerpts as the codices do. As Timothy Kearley notes, "The bulk of the novels, those of general application, were directed to the Praetorian Prefect of the [East], the Emperor's chief judicial officer, who was sometimes commanded in the law to make it widely known. This general publication often was done by writing the law on a tablet, or in stone, and displaying it in churches." ${ }^{14}$ Although the addressee named in many of the novels is the praetorian prefect of the East, copies were also sent to other prefects and officials in many cases.

As for canons, the history of how conciliar decisions were recorded differed in the East and the West. Many acts of local councils survive from the West. ${ }^{15}$ Much fewer do from the East. In the East, the canons of select councils of late antiquity were chosen as normative and transmitted in compilations. ${ }^{16}$ In addition, collections of canons in the East have been transmitted, not organized by the locale of the council but by the name of the presumed president, such as the canons of Athanasius of Alexandria. ${ }^{17}$ Much more historical work remains to be conducted before such collections, which survive in Greek, Syriac, Coptic, Arabic, and still other languages, can be used. The method of recording canons in the East adds a layer of complexity that must be addressed first in order that the canons themselves can be read critically. Therefore, I have omitted such compilations from the present study. For this reason, though the canons amassed in part I make it appear as though the West issued more than the East on the matter of ecclesial property, that is not necessarily true.

\section{DEFINING "ECCLESIAL PROPERTY"}

I use the phrase "ecclesial property" in the broadest sense. "Sacred things" included not only the church building and liturgical vessels, but also associated properties, 
such as revenue-producing lands or even slaves. To use legal parlance, it was not only immovable property (e.g., the church building) that counted as res sacrae, but also movable (e.g., the vessels) and self-moving (e.g., the slaves) property. "Ecclesial property" refers to the whole set.

My starting point for examining the legal status of ecclesial property in the Roman Empire is the pedagogical writings of jurists, who explained that sacred property has no owner, but rather falls under divine protection. This point has not escaped the attention of scholars who study Roman sacred law prior to the Christianization of the empire. ${ }^{18}$ However, although several studies have attempted to account for the legal status of Christian sacred places, they ask the question, "Who owned ecclesial property?" and debate whether the church at large was considered a corporate legal entity or whether each individual church was a legal entity. ${ }^{19}$ In so doing, these studies read the concept of ownership into laws and canons, instead of reading the laws and canons through the lens of Roman legal principles concerning sacred property. Other publications have focused on specific aspects of legal and canonical legislation: the topics of privileges, ${ }^{20}$ donations, ${ }^{21}$ alienation, ${ }^{22}$ manumission of slaves, ${ }^{23}$ and asylum..$^{24}$

This chapter analyzes how imperial and ecclesiastical legal discourse conceived of the category res sacrae by creating a means for controlling how sacred things were made and how they were administered. At the same time, the discourse established an "othering" process to keep the category of res sacrae in imperially sanctioned hands. The places that "heretics" claimed as their churches or res sacrae were denied these designations altogether and given instead demeaning appellations, such as "feral grotto."

\section{ROMAN JURISTIC PEDAGOGY ON RES SACRAE}

In the three centuries that preceded the legal legitimization of the Christian cult in the time of Constantine, Roman jurists published textbooks and commentaries, among other writings, that had become classic by the time of Justinian. So as to account for temples as things (res) in jurisprudence that distinguished among things (res), persons (personae), and actions (actiones), these writings defined a legal category of "sacred things" (res sacrae). Such writings, in turn, became the legal platform from which ecclesial property would be made into res sacrae.

Jurisprudence on res sacrae survives in three legal texts: two textbooks and a compilation. The textbooks, both called the Institutes, were written by a secondcentury Roman jurist, Gaius, and the sixth-century quaestor under Justinian, Tribonian, along with his staff. The compilation, the Digest, was likewise completed by Justinian's commission, and it contains excerpts from the writings of firstthrough early fourth-century jurists concerning res sacrae. Professional jurists such as Gaius, Tribonian, and those cited in the Digest not only formulated legal categories and delineated the realms of legal possibility, but they also taught other jurists 
their trade. Jurists' studies offered frameworks to be adhered to, reinterpreted, or rejected in the composition of imperial constitutions and ecclesiastical canons.

It is important to concede from the outset that what is cited in the Digest cannot be divorced from its sixth-century context. Though the excerpts derive from texts written prior to the legal legitimization of the Christian cult, they were selected and arranged according to the principles of a sixth-century commission. ${ }^{25}$ For this reason, it must be remembered that the picture of a pre-Justinianic category of res sacrae is colored by sixth-century choices as to which jurists should be quoted, which portion of their works should be cited, and with which citations they should be juxtaposed. In many cases, the Digest represents the only witness to certain jurists' otherwise lost writings.

\section{Res Sacrae as a Legal Category}

The jurists Gaius and Ulpian in the second and third centuries, respectively, and Tribonian in the sixth created a category of res sacrae foundational to the regulatory discourse of Christian sacred things. Gaius and Ulpian offer two different ways of categorizing res sacrae in their respective Institutes or legal textbooks. ${ }^{26}$ Whereas Gaius treats res sacrae as separate from all other res, Ulpian joins the sacred together with state offices. In Justinian's codification of jurisprudence, it was Gaius's schema that was chosen to underlie the Institutes, but the Digest opened with Ulpian's.

According to Gaius, there are things subject to divine law (res divini iuris) and things subject to human law (res humani iuris). ${ }^{27}$ They are distinguished by their relationship to "our patrimony" (nostrum patrimonium), which refers to the aggregate of things that are subject to ownership. ${ }^{28}$ Things under divine law lie outside of the patrimony (extra nostrum patrimonium), cannot belong to anyone (nullius in bonis), and are further subdivided into sacred (sacrae), religious (religiosae), and sanctified (sanctae) things. ${ }^{29}$ Res sacrae are consecrated to the gods above (diis superis consecratae sunt). ${ }^{30}$ In order to be properly consecrated, the consecration must occur under the authority of the Roman people (ex auctoritate populi Romani), either by means of a statute (lex) or by a Senate resolution (senatus consultum). ${ }^{31}$ In contrast, things under human law lie within the patrimony (in nostro patrimonio) and are further subdivided into public (publicae) and private (privatae). ${ }^{32}$

Ulpian, on the other hand, does not distinguish between divine law and human law. Instead, his framework divides public law from private law. ${ }^{33}$ Each category is further subdivided into three parts. Public law covers the sacred (in sacris), the sacerdotal offices (in sacerdotibus), and the magistracy (in magistratibus). ${ }^{34}$ Private law is divided into natural rules (ex naturalibus praeceptis), rules of all human beings ([ex] gentium [praeceptis]), and rules of communities ([ex] civilibus [praeceptis]). ${ }^{35}$ Res sacrae fall under public law and are treated under the same umbrella of legal theory that the offices of the priesthood and offices of the state are treated. ${ }^{36}$ "Private" is not as narrowly conceived as Gaius would have it, since it encompasses both personal and state rules. 
TABLE 1 Division of Things according to Gaius, Ulpian, and Justinian

\begin{tabular}{lccc}
\hline Gaius & Divine law, extra nostrum patrimonium & Human law, in nostro patrimonio \\
& & Sacred & Public \\
& Religious & Private \\
& & Sanctified & \\
\hline Ulpian & Public law & & Natural \\
& & Sacred & Private law \\
& Sacerdotal & & Civil \\
\hline Justinian & Magistracy & & \\
& Divine law, extra nostrum patrimonium & In nostro patrimonio & \\
& & & Natural \\
& Sacred & Public \\
& Religious & Communal \\
& Sanctified & Unowned \\
& & Individual \\
\hline
\end{tabular}

Justinian's Institutes distinguish between things within the patrimony (in nostro patrimonio) and things outside it (extra nostrum patrimonium).$^{37}$ Things that lie outside the patrimony fall under divine law and are further subdivided into sacrae, religiosae, and sanctae, as in Gaius's schema. ${ }^{38}$ It is here that ecclesial property is explicitly called res sacrae:

Sacred are those things that are consecrated to God ritually and by the pontiffs, such as sacred buildings and gifts, which are ritually dedicated to the service of God.

Sacra sunt, quae rite et per pontifices Deo consecrata sunt, veluti aedes sacrae et dona quae rite ad ministerium Dei dedicata sunt. ${ }^{39}$

Res sacrae are things properly consecrated to God by bishops-that is, church property. Things within the patrimony are further subdivided into five categories in Justinian's schema (see table 1 above). While Justinian's Institutes largely borrow from Gaius's subdivision of res, especially in the matter of categorizing res sacrae, his Digest begins with Ulpian's schema, and Justinian bound res sacrae closely with the imperial office. ${ }^{40}$ The table above summarizes Gaius, Ulpian, and Justinian's respective divisions.

Gaius conceived of res sacrae as things produced as a result of a particular ritual, the consecration, provided that a statute or senate resolution authorized the performance of such a ritual. Justinian's quaestor, Tribonian, and his staff would produce a category of res sacrae that also identified the ritual of consecration as the method of making res sacrae and that placed the authority for the performance of such a ritual in particular hands: those of imperially endorsed bishops. Ulpian not only associated sacred things with the ritual agents that produced them but also with the magistracy, and, in fact, from Constantine to Justinian, imperial offices 
would control Christian sacred things. In part, that control consisted of authorizing certain ritual agents and outlawing others. Though Tribonian would offer the only Christian definition of the category in Justinian's Institutes, the regulatory discourse of Justinian's imperial predecessors had already created means for controlling ecclesial property as sacred things.

Other excerpts in the Digest show in more detail how Ulpian defined the process by which res become res sacrae. Ulpian specifies how a thing becomes sacred, and he even describes the transformation as a change in the nature of the thing. Ulpian explains that for a place to become sacred, it must be dedicated publicly. ${ }^{41}$ If it is public land that is to be dedicated, the emperor or someone delegated by him should perform the dedication. ${ }^{42}$ Ulpian stresses the fact that the consecration must be properly performed for the place to attain legal status as sacred. His explanation invokes the scenario of fulfilling a vow. If someone vows to dedicate a thing, the vow places an obligation on the person not the thing. In fulfilling the vow, the person is released from his oath, but the object is not necessarily thereby sacred because the dedication may not have been performed properly. ${ }^{43}$

In a discussion of the way in which partnerships can be dissolved, Ulpian shows that the ritual of consecration changes the legal nature of a thing. When a person or a thing perishes, a partnership is dissolved. A person perishes by changing civil status, from slave to freedman, for instance (one juristic person perishes, another is created by the change in civil status). Likewise, things perish when they change their nature-for example, through consecration or confiscation. ${ }^{44}$ According to Ulpian, then, the thing perishes, receives a new nature by virtue of the consecration, and becomes a res sacra.

Gaius's juristic pedagogy in the Institutes and those of Ulpian quoted in Justinian's Digest show that prior to the legal legitimization of the Christian cult, Roman jurists had created a category of res sacrae and asserted governmental control over sacred things. Justinian's Institutes show that in the sixth century jurists continued to reproduce the same category but with specific reference to Christian practices and ritual agents. In pedagogical literature of the second, third, and sixth centuries, jurists identified the consecration rite as the legal means by which a thing becomes sacred. Justinian's rewriting of classical legal principles singled out bishops as the ritual agents who performed consecration rites to produce sacred things.

\section{THE MAKING OF CHRISTIAN RES SACRAE}

Prior to Justinian's codification project, no pedagogical literature "translated" Roman juristic principles for a Christian imperial context. Nevertheless, from Constantine's legalization of Christian practices through Justinian's codification project, jurists and bishops conceived of regulations in order to make, identify, and control Christian sacred things. Jurists composed laws, and bishops composed canons, both of which relied on classical Roman juristic pedagogy. 
Bishops exercised two main forms of control: they regulated the consecration ritual as well as the administrative obligations of the ritual agents and their subordinates. Under Justinian, laws would be written to exercise the same forms of control. However, pre-Justinianic jurists primarily engaged in different methods of control: they labeled certain ritual agents as adherents of the "true faith," outlawed others, and confiscated properties that "ought not be called churches." In other words, while jurists usually engaged in practices to restrict the application of the category "sacred thing," bishops usually regulated ritual practice and the administrative duties of ritual agents.

As the following sections detail, bishops (1) outlined prerequisites for a consecration rite to occur, (2) established rules about which bishops might preside over the ritual, and (3) decided the circumstances under which churches might be reconsecrated. Though all canons (and laws) assume bishops, priests, deacons, and other clerics to be the administrators of ecclesial property, some further legislate about how they ought to administer those properties, about how to use ecclesial property as res sacrae, and about how to adjudicate cases of mismanagement. As for res sacrae on private estates, they were subject to special administrative regulations so as to ensure episcopal control of them, as will be detailed below. After the review of all the relevant laws and canons, a case study of a fifth-century church in Libya illustrates how such regulatory principles affect our interpretation of a specific conflict.

\section{Rules on the Consecration Ritual}

Bishops (and some jurists) at various times and places created two principles for the making of sacred things: (1) that only rightly authorized bishops can make churches, and (2) that once a church is made, it remains a church in perpetuity. I examine each of the rules in turn, noting general principles and any penalty schedules. Penalty schedules offer a means of assessing how grievous jurists or bishops considered any given infraction. The most severe penalty legally was capital punishment; canonically, it was excommunication and cursing.

Prerequisites for the Consecration. Bishops of Gaul and Spain and jurists of Justinian's empire set standards for the making of churches that would enable them to remain fully functioning sacred things indefinitely. To ensure perpetuity, financial prerequisites had to be met before ecclesial property could be consecrated. For this reason, the Councils of Epaon, Gaul, in 517 and Braga, Spain, in 572 forbade the consecration of churches that lacked a sufficient endowment. ${ }^{45}$ In 538 , Justinian issued a similar regulation, but he added a means by which one might be named a "founder" without building and endowing a church from scratch. ${ }^{46}$ Justinian established an incentive to encourage individuals to endow already built churches, since

many people, for fame's sake, embark on the construction of most holy churches, but after having built them do not go on and see to setting aside funds sufficient for 
lighting them, for the support of those serving there, and for sacred ministry; they leave them as just bare buildings, either decaying, or deprived of all sacred ministry. ${ }^{47}$

Even though such individuals merely endowed churches in need, they would nevertheless be considered "founders." To prevent future iterations of the same problem, Justinian ruled that no one might build a church or chapel unless (1) the bishop of the place visited the land first by going there publicly, offering vows, and affixing a cross, and (2) the founder endowed it with money for lighting the lights, the sacred ministry, maintenance of the house, and support of those engaged therein. ${ }^{48}$ Before a church was built, the ritual agent who would consecrate it first had to grant his approval publicly by dedicating the place. A place was not to become a church unless it could remain a church in perpetuity.

The Ritual Agent. Bishops also controlled the production of sacred things by assigning specific ritual agents to the task. The bishop of a region had to make the churches of that region; no one else could. ${ }^{49}$ The consecration rite became a means by which bishops' jurisdictional boundaries were reified, since bishops could only produce sacred things within their own jurisdiction. A bishop was not supposed to perform a consecration on behalf of another or to widen his own jurisdiction. According to the First Council at Orange, Gaul, in 441 the bishop of the diocese in which the church was built had to consecrate it, regardless of who built the church. ${ }^{50}$ The canon mentions two particular scenarios to which the rule applies: (1) a bishop obtains permission to build a church in another bishop's diocese; and (2) a layperson who built the church invites a bishop from another diocese to consecrate it. The responsibility for the consecration fell to the bishop of the diocese, regardless of the circumstances. In 538, the Third Council of Orleans, Gaul, added a qualification and a penalty. ${ }^{51}$ If it so happened that a bishop consecrated a church outside his diocese, the consecration was valid, but the offending bishop would be suspended for a year for disrespecting the prerogative of the diocesan bishop. As the case study below shows, Synesius of Cyrene expressed a different opinion about the validity of consecrations improperly performed. A later council at Orleans decided that even extenuating circumstances would not affect the rule about who might produce which churches. Even if the bishop were recalled or there were no bishop for an indefinite period of time, the consecration of altars could not occur until a new bishop were installed. The bishop of a diocese had to make the sacred things of his own diocese no matter what. ${ }^{52}$

The Reconsecration of Churches. In legal theory, once a sacred thing was made, it was a sacred thing for all time, and could not be "remade." While bishops adhered to this principle of production, they also faced circumstances for which they deemed reconsecration advisable. The Fourth Council of Carthage in 401 addressed the question: if it is unknown whether a church has been consecrated, 
should the consecration take place even at the risk of reconsecrating it? ${ }^{53}$ To answer this question, the assembled bishops drew an analogy between churches and persons. ${ }^{54}$ The policy regarding consecration was to follow that of baptism. A person could be baptized if it were uncertain whether he or she had been baptized; therefore, a church was to be consecrated if it was uncertain whether it had been consecrated.

More commonly, the issue of reconsecration arose when bishops acquired the churches of heretics. To consecrate the place anew would reinscribe the same principle of production named above: that only the bishop of a diocese-in this case, the only "true bishop"-could make sacred things in his diocese. Heretic churches were "never really" churches in the first place, so a consecration could be merited. While the bishops of a council at Orleans decided that a church of heretics ought to be consecrated like any other place, ${ }^{55}$ those at Epaon chose to regard heretic churches as impure and unusable unless they had been formerly orthodox. ${ }^{56}$ At the end of the sixth century, a council at Saragossa, Spain, required the reconsecration of certain Arian churches. ${ }^{57}$ If a church had been consecrated by an Arian bishop prior to his reordination as a catholic, then it had to be reconsecrated by him as a catholic. These rules delegitimized the sacrality of heretics' churches by either declaring them unusable or requiring their consecration by the "orthodox" ritual agent.

\section{Rules on Administrative Obligations to Res Sacrae}

Although a bishop's production of a sacred thing was an unrepeatable one-time act, his performance of the ritual bound him to an episcopal career of obligations toward that sacred thing. As the following rules show, conciliar assemblies decided what those obligations were, constructed a subordinate administrative body to assist the bishop, and created policies and procedures for addressing allegations of administrative misconduct. Such decisions reveal how the regulatory discourse of ecclesiastical assemblies produced res sacrae as objects of bishops' purview even after the occasion of consecration.

The Bishop as the Chief Administrator. Bishops were obligated to administrate res sacrae for pious purposes only, above all for the benefit of the poor and needy. This point is emphasized in early canons described below and likely led to the petitions discussed in chapter 3 and contributed to the conceptual framework of the ritual economy analyzed in part II.

As early as 330, a council at Antioch set forth the administrative duties of the bishop in detail. ${ }^{58}$ The council made it incumbent on the bishop to administer ecclesial property for the benefit of the poor with discretion and the fear of God. He could use it for his needs, if necessary, and for the needs of those who received his hospitality, but he could not use it for his own ends or for those of his relatives. 
He had to render account to the synod, and if he were to be accused of maladministration to the detriment of the poor, the synod would hear the case.

A reworking of the Council of Antioch's canon in the late fourth-century collection called "The Canons of the Apostles" labels the bishop, in his chief administrative duty, "oeconomus of God" ( $\theta \varepsilon \circ \hat{v}$ oikovó $\mu$ ○) and the ecclesial properties over which he exercises his administrative duty "the things of God" ( $\tau \dot{\alpha} \tau \circ \hat{v} \theta \varepsilon \circ \hat{v}){ }^{59}$ Such phrases echo the jurist Gaius's (and later Justinian's) teaching that sacred things are under divine law. They are consecrated to God and are therefore "the things of God." The bishop administers them on behalf of God as God's steward. Another canon from the same collection offers justification for the bishop's role as the oeconomus of God: if he is responsible for the precious souls of men, how much more so ought things to be in his trust? ${ }^{60}$ Still another canon from the collection echoes the Council of Antioch's priorities for a bishop's use of ecclesial property. Bishops had to distinguish their personal property from that of the church. ${ }^{61}$ In 589, a council at Toledo, Spain, reiterated the duty of the bishop to use ecclesial property for the benefit of the poor and strangers and in support of the clerics. ${ }^{62}$

Justinian would codify into law the ecclesiastical prerogative to protect ecclesial property for the poor and from the administrators and their relatives' personal needs by preventing certain kinds of individuals from becoming bishops. In 528, Justinian decreed that no one could be appointed bishop who had children or grandchildren for the following reason. ${ }^{63}$ According to the law, donations to churches are made with hope in God, for the salvation of one's soul, to relieve the poor and needy, and for other pious purposes. Therefore, it was not right that the bishop should use them for his own sake or that of his relatives. I will return to this issue of familial interests in the administration of ecclesial property in chapter 2.

The Oeconomus as Deputy Administrator. All clerics assisted the bishop in his administration of sacred things, but the Council of Chalcedon in 451 formally instituted the office of the oeconomus or steward to serve as the direct deputy to the bishop. ${ }^{64}$ The council explained why the office of the steward ought to be established: the multiplicity of accusations against bishops concerning ecclesial property threatened the dignity of the priesthood. ${ }^{65}$ The steward would prevent the loss of ecclesial property to both clerics and episcopal kin and assist the bishop in property administration, thereby distancing ecclesial property from the bishop's ties of kinship and the "dignity of his priesthood" from accusations. The steward would stand between bishop and property, so that accusations of administrative misconduct would affect the steward, though the bishop remained the chief administrator. The canon checked the bishop's administrative power by introducing a deputy administrator, but it also protected the bishop himself by introducing someone else who would suffer blame and penalties for administrative misconduct. 
Indeed, Justinian's penalties against maladministration are usually directed against the oeconomus, not the bishop.

Justinian required stewards to render an account of their administration to the bishop of their own diocese on an annual basis. ${ }^{66}$ If they died before rendering an account, their heirs would be subject to audit and responsible for making any restitutions. Apocrisarii (episcopal deputies at the capital), on the other hand, were legally protected under Justinian from answering suits regarding ecclesial property or being subject to exaction, unless the bishop or steward whom they represented required them to sue someone. ${ }^{67}$

The Administrative Duties of Clerics and Their Relationship to the Bishop. Ecclesiastical regulatory assemblies also placed the responsibility for administrating res sacrae on the shoulders of other clerics, such as priests. ${ }^{68}$ The Council of Ancyra in 314 underscored their subordinate relationship to the bishop in addressing priests' administration of ecclesial property during the vacancy of an episcopal see. ${ }^{69}$ Priests (prior to the Council of Chalcedon's institution of the office of the "steward") were to fulfill certain episcopal administrative duties during a vacancy, but the succeeding bishop held the prerogative as chief administrator to undo the priests' legal actions.

For Justinian, one important way in which clerics were supposed to demonstrate responsibility for ecclesial property was to fulfill their liturgical duties, such as chanting. Since donations were made in order that the sacred services could be performed, the clerics had to be faithful in practicing worship. ${ }^{70}$ Donations placed an obligation on the clerics to fulfill the kinds of duties for which the donations were made.

In sixth-century Gaul, canons were issued that leveled penalties against clerics for shirking their duties as property administrators subordinate to the bishop. A council at Arles in 554 decided that if clerics neglected the properties entrusted to them by the bishop, the junior ones were to suffer corporal punishment and the senior ones were to be regarded as murderers of the poor (necator pauperum) ${ }^{71}$ The latter was a typical penalty imposed by councils in western regions for abuse of ecclesial property. ${ }^{72}$ The sentence reinforced what previous councils in other regions had identified as the core responsibility of the bishop: to administer sacred things for the benefit the poor. The Council of Narbonne in 589 required clerics who abused their administrative duties to return ecclesial property to the trust of the bishop, excommunicated them, and imposed a period of two-year penance before they could resume their clerical position. ${ }^{73}$ The council targeted two types of abuse in particular: stashing away property and committing fraud with it.

The Administrative Relationship of Bishops to Fellow Bishops. Ecclesiastical regulatory assemblies established administrative bodies in such a way that bishops 
were independently responsible for the res sacrae in their jurisdiction. Bishops' relationship to other bishops primarily consisted of respecting one another's jurisdictional boundaries. Two councils adjudicated the problem of bishops appropriating ecclesial property entrusted to other bishops. First, the Council of Chalcedon in 451 allowed bishops to retain parishes they held uncontested for a prescriptive period of thirty years. ${ }^{74}$ Second, a council at Lyons, Gaul, sometime between 518 and 523, barred bishops from annexing the parishes of another bishop. ${ }^{75}$

Policies and Procedures for Adjudicating Cases of Maladministration. As mentioned above, the Council of Antioch in 330 designated the synod as the court for trying cases of episcopal maladministration. ${ }^{76}$ In 382 , the Council of Constantinople published specific policies for resolving such cases. ${ }^{77}$ The synod cited the following reason for creating policies: too many people leveled accusations against orthodox bishops. To resolve a perceived problem of excessive lawsuits, the synod set limitations on whose accusations would be heard. The synod would only hear the cases of orthodox plaintiffs in good standing with the church. While the cases of all, without distinction, would be heard regarding personal or private accusations, ecclesiastical accusations could only be leveled by orthodox plaintiffs in good standing with the church. No heretic or excommunicated, condemned, or accused individual would be permitted as a plaintiff against a bishop or cleric. The synod also established a procedure for hearing accepted cases. Members of the provincial synod (eparchy) would hear the case first; if unresolved, then a greater episcopal assembly of the diocese would hear it. No one would be heard if he or she ${ }^{78}$ evaded this procedure by addressing the emperor, a civil authority, or even an ecumenical council. The Council of Chalcedon in 451 would further require an examination of the plaintiff's character, regardless of whether he or she were a layperson or a cleric, before a synod could accept the accusation, let alone schedule a hearing. ${ }^{79}$

Justinian reiterated canonical due process for leveling a lawsuit against members of the ecclesiastical administration in a constitution of 530, but he also clarified the procedure for making appeals and he set limits on the fees that could be exacted. ${ }^{80}$ Like the Council of Constantinople in 382 , he emphasized that due process could not be bypassed. For example, an accusation against a cleric had to be heard by the local bishop first (the suit could not be brought immediately to the patriarch, for instance). The system of appeals consisted of three successive levels: the metropolitan judged a first appeal; the provincial council of bishops judged a second appeal (with the three most senior bishops as judges); and the patriarch judged a third and final appeal. As for fees, plaintiffs could be asked to pay as much as six solidi for suits against bishops, and one-sixth of a solidus for suits against any other cleric. The penalty for exacting more than the prescribed fees was that the plaintiff would receive double what he or she paid, and the cleric who imposed the excessive fee would not only be disciplined by his metropolitan or patriarch; he would also be defrocked. ${ }^{81}$ 


\section{Rules on Res Sacrae at Private Estates}

Councils created and enforced conceptions of how to make res sacrae and how to administrate them not only for the purpose of making and managing publicly available churches and properties. Res sacrae could be made on private estates, too, and such foundations were usually referred to as an "oratory" (oratorium)

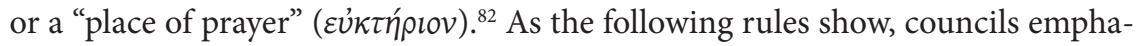
sized the sanctity of such places and produced special regulations so as to assert episcopal control over them. Councils stretched the arm of episcopal control in three major ways: (1) by requiring the bishop's approval of the establishment; (2) by requiring the bishop's approval of the celebrants; and (3) by restricting the rites that could take place in res sacrae on private estates. Each of these will be discussed in turn below.

The Founding of Res Sacrae at Private Estates. As mentioned above, Justinian would require that bishops offer their consent to the building of a new church or oratory before the construction process took place by dedicating the land publicly with vows and the installation of a cross. ${ }^{83}$ Earlier, the Council of Chalcedon in 451 specifically required that the metropolitan (the bishop of the city) grant his consent before the construction of res sacrae on private estates anywhere in his jurisdiction could take place. ${ }^{84}$ Emperor Marcian proposed this rule in the sixth session of the council, and his draft was lightly edited for inclusion in the council's canons. $^{85}$

Just as the sixth-century councils in Gaul and Spain and Justinian's law mentioned above required churches to be sufficiently endowed before being built, a sixth-century council at Orleans imposed similar prerequisites before an oratory could be built. Whoever would build an oratory on his or her private estate also had to endow it for two reasons: for the well-being of the clerics who served there and so "that right reverence be accorded to the sacred places (sacratis locis)." ${ }^{86}$ The latter reason is especially significant. Even oratories were sacred, and bishops insisted that the same method of production and management created for churches be applied to oratories as well.

Further rules bishops made for their administration and management show that the proprietors of such private estates did not always welcome the bishop's control of the oratory. In response, bishops, like those at Orleans, drew special attention to the sanctity of the place so as to justify their control, as the following section explains.

Episcopal Administration of Res Sacrae at Private Estates. In fact, the mid-fourthcentury council at Gangra, Asia Minor, asserted episcopal control by affirming respect for "all places built for the honor of the name of God," not just "the houses of God" (i.e., publicly available churches). ${ }^{87}$ Since oratories, like churches, were sacred, the council insisted that a priest agreed on by the bishop celebrate any 
services held in them. ${ }^{88}$ Two centuries later, a council at Orleans, Gaul, required the bishop's approval for itinerant clerics to serve in oratories. ${ }^{89}$

Landowners of estates with oratories met not only with episcopal but imperial oversight, too. In 398, Emperor Honorius acknowledged episcopal jurisdiction over oratories on private landholdings in a constitution issued to the region of Illyricum. ${ }^{90}$ For tax purposes, however, he limited the freedom of bishops to assign clerics to oratories. So that the landholders could not avoid the capitation (or poll) tax for the clerics working on their estates, Honorius required of the bishops that the clerics they appointed to serve on such landholdings be residents of the village on which the landholding was located and not come from other municipal jurisdictions.

Permissible Ritual Practices in Res Sacrae at Private Estates. Though bishops emphasized the sanctity of res sacrae on private estates so as to justify their oversight, bishops (and jurists, too) also undercut such claims by restricting the kinds of liturgical celebrations that could take place in oratories. The late fourth-century council at Laodicea did not permit the eucharist to be celebrated in oratories. ${ }^{91}$ In contrast, early sixth-century councils at Agde and Clermont did allow the celebration of the eucharist in oratories built outside the region of the parish, but not on major feast days, such as Easter, Christmas, Epiphany, Ascension, Pentecost, the Birthday of John the Baptist, among others. ${ }^{92}$ The bishops of the council threatened excommunication to anyone who would celebrate such major feasts in oratories without the express permission of the bishop. A council at Dovin, Armenia in 527 did not permit baptism to take place at private estates. ${ }^{93}$ The Synod of Auxerre, Gaul, sometime between 561 and 605 forbade the celebration of the eucharist, nocturne vigil, and feasts of saints in particular houses. ${ }^{94}$ It also restricted the making of vows to publicly available churches and added that they had to be made to the benefit of clerics and the poor.

Justinian enforced similar rules in two of his laws. In 537, he forbade the celebration of the mysteries in home chapels. ${ }^{95} \mathrm{He}$ declared that oratories on private estates could only be used for the purpose of prayer, unless the bishops provided a cleric for the celebration of a mystery there. A house that violated the rule would be confiscated to the imperial treasury, but a three-month grace period to make arrangements to accord with this law was given to those houses already in violation at the time of promulgation. Failure to enforce the law would result in a fiftypound gold fine to the office of the prefect. By 545, the confiscation of such houses would no longer benefit the imperial treasury. ${ }^{96}$ Instead, patrons lost their rights over their estate chapels, and bishops, stewards, and the civil magistrate could make a claim of the property for the church. If the owner was not to blame for the violation, but rather the procurators or lessees or emphyteuticaries (lessees of land), then they were to be expelled from the province and their property claimed by the church. Such laws added civil consequences to rules that bishops had 
already created. If patrons failed to cooperate with episcopal oversight of their oratories, they or their subordinates could face loss of property through confiscation that initially benefited the imperial treasury, but in later years enriched the bishop's diocesan landholdings.

\section{A DISPUTE OVER A CONSECRATED CHURCH IN LIBYA}

Synesius of Cyrene became metropolitan bishop of Ptolemais, Libya on January 1, 412. ${ }^{97}$ In less than five weeks, Synesius faced some of the same issues in the production of res sacrae as those expressed in the canons discussed above. He traveled approximately fifty kilometers east to villages of Libya Inferior (also known as "Arid Libya") to resolve the matters. ${ }^{98}$ Synesius offers a detailed account of his assessment and provisional resolution of a conflict between two neighboring bishops over a consecrated church in a letter addressed to his superior, Theophilus, the bishop of Alexandria. ${ }^{99}$ From Synesius's epistolary account, one may infer Synesius's answers to the questions: What procedure should be followed to hear a case against a bishop? How ought churches to be produced? What should the consequences be if a bishop improperly made a res sacra? Synesius's report shows how he and a Libyan provincial synod operated with the regulatory principles observed above in order to propose a resolution suited to local exigencies.

As mentioned above, the Council of Constantinople in 382 outlined policies and procedures for the adjudication of episcopal disputes. ${ }^{100}$ All the Libyan bishops involved followed those procedures. A provincial synod in Ptolemais had already heard the case and resolved it in favor of the prosecution, Dioscurus of Darnis. ${ }^{101}$ The defense, Paul of Erythrum, appealed the case to Theophilus. ${ }^{102}$ Theophilus sent the head of the provincial synod, Synesius, to investigate the matter first.

Synesius's letter to Theophilus details the results of his investigation. Synesius reported that (1) he held a hearing for the people of the villages of Palaebisca and Hydrax; ${ }^{103}$ (2) he conducted an inspection of the disputed territory in the presence of the same provincial synod that had adjudicated the case; ${ }^{104}(3)$ in the course of the inspection, he oversaw a negotiation between Dioscurus and Paul; ${ }^{105}$ (4) in accord with Dioscurus's request, Synesius sent Theophilus a detailed report concerning the arbitration; ${ }^{106}$ and (5) Synesius held a second hearing for the people of Palaebisca and Hydrax, at which time the people nevertheless submitted a petition appealing the case to Theophilus. ${ }^{107}$ How Theophilus responded, we do not know, but Synesius and the provincial synod did not suspend Paul for overstepping his jurisdictional boundaries. ${ }^{108}$ Synesius's temporary resolution of the conflict took place at an ecclesiastical inspection of the hill in dispute, where Synesius and the provincial synod allowed the two bishops, Paul and Dioscurus, to redraw the jurisdictional boundary. The people of Palaebisca and Hydrax, nevertheless, insisted on appealing the case to Theophilus. First, I will describe the territory in dispute. Then I will explain how Synesius provisionally resolved the conflict. 
The two bishops, Paul of Erythrum and Dioscurus of Darnis, vied for control of a hill in Palaebisca and Hydrax, on which the ruins of a former fortress lay. ${ }^{109}$ In the course of prior conflicts over the episcopal succession of Erythrum, the jurisdictional territory had been divided, then reunited, and divided again. ${ }^{110}$ Paul consecrated a building in the fortress ruins so as to acquire the hill from Dioscurus's territory. Paul claimed to have jurisdiction of the site, but Dioscurus accused Paul of using fraudulent means to obtain that jurisdiction: Paul consecrated to

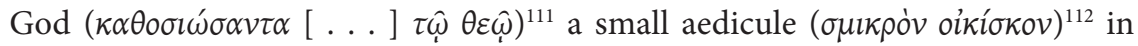
Dioscurus's jurisdiction. To resolve the dispute, Synesius and his synod inspected the locale in question, made a decision, and allowed Dioscurus and Paul to engage in a compromise.

In his defense, Paul of Erythrum made two claims: (1) that he and his predecessors had used the building as a church long before it came into the jurisdiction of Dioscurus of Darnis; ${ }^{113}$ and (2) that he (Paul) had consecrated the building. Synesius responded to Paul's first claim much in the same way as Athanasius responded to Constantius II. Use of the site as a church does not thereby make it a consecrated church:

The fact that a crowd of men have once prayed there by necessity, driven in by hostile attack of the enemy, does not consecrate the spot, for at that rate all the mountains and all the valleys would be churches, and no fortress would escape being a place of public worship, for in all such places, when the enemy are out for plunder, prayers and celebrations of the Holy Mysteries take place. ${ }^{114}$

As Athanasius had claimed to Constantius II, celebration of the mysteries in a place did not entail the consecration of that place. Synesius cited recent history as precedent. When the "enemy Arians" had the ascendancy, their opponents took flight and performed many prayers and sacred ceremonies in houses. Those houses nevertheless remained private property. ${ }^{115}$

Synesius not only dismisses Paul's claim to the site prior to Dioscurus's control of it, but he also dismisses the validity of Paul's act of consecration, contrary to the canons cited above. Although the canons discipline bishops who make sacred things outside their jurisdiction, they nevertheless treat the consecration itself as valid and unrepeatable. ${ }^{116}$ Synesius, on the other hand, considered even the consecration invalid on account of bad faith on the part of the ritual agent. The two different opinions (those of the canons and that of Synesius) about weighing the relevance of good or bad faith align with opinions classical jurists had expressed centuries prior. Like Synesius, Pomponius, a second-century jurist, emphasized the importance of good faith in assessing the validity of a legal act. By contrast, Modestinus, a third-century jurist, did not think that an individual's intentions mattered for assessing the validity of an act; instead, the issue of good faith made a difference in the type of legal action the individual could pursue to redress a wrong. ${ }^{117}$ 
To evaluate Paul's intentions, Synesius asked if Paul had acquired the land from Dioscurus by gift or agreement in advance of the ritual, and he learned that Paul had in fact asked for the fort but that Dioscurus had refused his request. Despite the refusal, Paul took a small table and consecrated a small aedicule on the hill. Synesius concluded that Paul did not conduct the consecration in good faith. In fact, Synesius called Paul's consecration "a method of confiscation," and he accused Paul of using "holy things" as "weapons:"

Clearly it had been calculated that by this manoeuvre the hill could be definitely acquired. For my own part, this whole performance seemed to me unworthy, more than unworthy, and I was very angry at this flagrant violation of all sacred laws and civil forms of justice alike. All things become confounded, if on the one hand a new form of confiscation is invented, and if on the other by the holiest things the most abominable should be judged, prayer, the table of the Holy Communion, and the Mystic Veil becoming instruments of a violent attack. ${ }^{118}$

Synesius regarded Paul's act of consecration as an act of superstition ( $\delta \varepsilon l \sigma l \delta \alpha \imath \mu o v i ́ \alpha \nu)$ and therefore an illegitimate ritual, not one of piety $(\varepsilon \dot{\sigma} \sigma \varepsilon \beta \varepsilon i ́ \alpha \varsigma) .{ }^{119}$ Synesius supported his opinion on the consecration's invalidity with two reasons: (1) "nothing [is] sacred or holy except that which has come into being in justice and holiness;" and (2) the Holy Spirit would not come to a place ruled by anger, senseless spirit, and contentious passion. ${ }^{120}$ Not only did the wrong agent attempt to produce a res sacra, but his intentions in producing it were of such a sort that admitted of no sanctity. Still, Synesius did not go so far as to declare the consecration invalid. Instead, he strove to transfer the place back into the hands of Dioscurus.

Synesius and the provincial synod paid a visit to the site to conduct an ecclesiastical inspection, and it was at the inspection that Paul and Dioscurus engaged in negotiation. Since the boundary stones and the testimony of elders indicated that the fortress belonged to the jurisdiction of Dioscurus, the synod reaffirmed its decision in favor of Dioscurus. ${ }^{121}$ The judges declared that Dioscurus had rightful claim to the hill, and Dioscurus's brother insisted that Paul's letter of appeal to Theophilus be read aloud. Synesius "read publicly the abusive paper that the blessed Paul had written in the shape of a letter addressed to your holiness, an obscene and unpleasant satire directed against his brother [Dioscurus], of which the burden of shame fell upon him who had spoken evil, not on him of whom evil had been spoken." 122 Paul "confess[ed] his error" and "gave evidence of his change of opinion more convincing than any rhetoric." 123 Since Dioscurus accepted Paul's repentance, he offered Paul concessions.

In accepting Paul's admission of wrongdoing, Dioscurus permitted Paul to purchase certain grounds of the fortress ruins in order to bring them into the jurisdiction of Erythrum: the vineyards and olive groves in addition to the hill where he had consecrated a small room. ${ }^{124}$ Synesius and his synod judged that Dioscurus should retain his jurisdiction, even after the wrong bishop produced a 
res sacra where only Dioscurus could, but Dioscurus and Paul chose to engage in compromise. The synod honored the decision the two bishops made for their local circumstances, even though it conflicted with the synod's judgment and even with prohibitions on alienating res sacrae.

As a result of the compromise, Paul purchased property that he had already consecrated. As chapter 2 will demonstrate, res sacrae could not be objects of sale, except under specific extraordinary circumstances. It is probably for this reason that (1) Synesius expressed reasons for invalidating the consecration of the building and (2) Dioscurus insisted that Theophilus be appraised of every detail of the compromise. ${ }^{125}$ However, as mentioned above, we do not know how Theophilus addressed the case once the documentation of Paul and Dioscurus's provisional compromise and the petition of the people of Palaebisca and Hydrax reached him.

In sum, Synesius and his synod did insist on episcopal respect for jurisdictional boundaries when it came to consecrating churches, a principle expressed in conciliar canons. However, the case also shows how local appeals could affect the situation, especially when there existed a prior history of shifting jurisdictional boundaries. Because Dioscurus was willing to compromise, he did not retain jurisdiction of certain parts of the region to which the synod declared he had rightful claim. Instead, Dioscurus made an agreement with Paul, in the presence of and with the support of the synod, to cede areas of his jurisdiction to Paul by sale, including a small aedicule that Paul ought not to have consecrated. Synesius's letter does not mention whether the synod officially repudiated the validity of the consecration and required a reconsecration; Synesius only expresses his own opinion on the matter to Theophilus (namely, that Paul's consecration of the small building was invalid). Synesius described Paul of Erythrum as one who tried to "confiscate" ( $\delta \eta \mu \varepsilon v ́ \varepsilon l v)$ areas of another bishop's jurisdiction. ${ }^{126}$ Though we cannot know how Theophilus weighed Dioscurus and Paul's provisional compromise against the appeal of the people of Palaebisca and Hydrax, it is clear that the episcopal bodies set up to administrate res sacrae produced and implemented policies and procedures to discipline or check bishops who created res sacrae outside of their jurisdiction.

On the other hand, emperors, jurists, and bishops did often acquire others' churches by renaming and confiscating them, as the following section shows. There was no legal means of unmaking or deconsecrating a res sacra (once a thing was consecrated, it remained a sacred thing whenever it was in the right hands), but there was a legal way to delegitimize others' sacred things: confiscation.

\section{CONFISCATION: THE LEGAL DELEGITIMIZATION OF OTHERS' CHURCHES}

Emperors, jurists, and bishops not only created sacred things; they also produced ways of identifying "faux" sacred things and eliminating them from the sacred 
landscape. "Faux" sacred things were produced by those who were legally recognized as "heretics" or "schismatics." ${ }^{27}$ Legal ways to identify "faux" sacred things included (1) labeling such places "meeting places" rather than "churches", (2) confiscating places where "forbidden practices" occurred, and (3) penalizing the ritual agents who engaged in forbidden practices and the landholders or civil officials who allowed or turned a blind eye to the forbidden practices. In what follows, I review each law, noting the general principles and citing the penalty schedules (which, as mentioned above, indicate the level of severity of any given infraction). The case study focuses on one region, showing how a fine of ten pounds of gold originally issued against heretics in the prefecture of the East became a symbol of a century-and-a-half long struggle in North Africa over rival sacred spaces.

\section{The Identification of "Faux" Churches}

Theodosius I declared to the people of Constantinople in 380 that the meeting places of those who do not hold the right faith are not to be named "churches." 128 Instead, such assemblies should be called conciliabula, "meeting places."129 A canon from a late fifth-century Gallic collection echoes Theodosius's refusal to acknowledge such places as churches: "The meeting places of heretics are not to be called ecclesias but conciliabula." 130 Though most constitutions did usually employ the neutral word conciliabula to refer to heretics' churches, some even used polemical designations. For example, a constitution issued against the Montanists in 415 calls their churches "feral grottos" (antra feralia) - that is, cavernous death traps. ${ }^{131}$

The exception proves the rule. One constitution against Manichaean churches calls them "churches." ${ }^{132}$ When the constitution was excerpted for the Codex of Justinian, the word "churches" was rewritten. The sixth-century version replaces "churches" with "[gathering] places (conventicula) of heretics-which they brazenly try to call churches (ecclesias)." ${ }^{133}$ In general, laws refused to ascribe any sanctity to heretics' churches. This shows that jurists controlled even the nomenclature of sacred places.

Emperor Leo I (who ruled from 457 to 474) even accused the heretics themselves of opposition to sanctity. In other words, he attributed to the heretics the legal reasoning that jurists had in fact created. In 466 , Leo tried to prevent sacred things on private estates from passing into the hands of heretics through a transaction involving the entire private estate. He passed a law that "estates, properties, and immovable property, where churches or chapels of the orthodox faith are located" could not be alienated, not even by a last will, to a heretic or anyone opposed to the orthodox faith in the East. ${ }^{134}$ If such alienation occurred, then the lands or possessions would be confiscated to the fisc (that is, the imperial treasury). Most importantly, Leo offered a rationale as to why heretics could not control sacred things: if heretics successfully gained possession of such lands, the churches would perish, because heretics "vehemently wished [they] did not exist." 135 Churches of heretics could not be churches because the heretics themselves opposed sanctity. 
Jurists produced and controlled the sacred landscape, but they employed antiheretical rhetoric to mask their control. Heretics' churches were not churches, not because the jurists made it so, Leo insisted, but because heretics opposed sanctity.

The jurist Ulpian had already composed a criterion for a valid consecration in the early third century, but the laws that confiscated heretics' churches developed more detailed measures for identifying faux sacred things. Ulpian's criterion was that a place had to be properly consecrated to be a res sacra. Ulpian's contemporary, Marcian, explained that only public authority, not private, could make a thing sacred. ${ }^{136}$ The same principle would make its way into Justinian's Institutes, where faux churches are called quasi sacrum. ${ }^{137}$ Confiscatory laws added that a church was not a church if "forbidden practices" took place there or "forbidden officiants" served there.

As the following section shows, the churches of heretics and sometimes schismatics were to become imperial, fiscal, public, or sacred property. ${ }^{138}$ When the churches of heretics were handed over to imperially recognized ecclesiastical administrators, they could become res sacrae. As noted above, two canons from sixth-century Gaul and Spain required such churches to be newly consecrated, but another from Gaul did not permit them to be used at all. ${ }^{139}$

\section{Imperial Procedure and Policies of Confiscation}

Churches could be located on two kinds of property. First, a church could be located on a wider plot of ecclesial property, in which case both the church and the associated properties were res sacrae. Second, a church could be located on a private landholding, in which case only the church itself was a sacred thing, but the rest of the property was not. In general, from 372 to 545, emperors would confiscate the latter kind of heretics' property to the fisc (the imperial treasury) or the public, but the former would be vindicated to imperially endorsed ("catholic") administrators. Fifteen imperial constitutions transfer the meeting places of heretics to the ownership of the fisc, the imperial treasury, or the public; ${ }^{140}$ twelve, to the catholic administrators of ecclesial property. ${ }^{141}$

The procedure of confiscation would typically occur as follows. The palatine office (officium palatinum) was responsible for each constitution's enforcement. ${ }^{142}$ Various judges could impose the penalty of confiscation, while the count of the res privata would register and manage confiscations. Authorities were not permitted to occupy the properties before the sentence was declared, and an appeal could suspend the procedure of confiscation. ${ }^{143}$ An inventory would take place at the ordinance of the governor who made the sentence, and a seal would be posted on the doors or on movable property to avoid property diversion prior to the inventory. ${ }^{144}$ The procedure for taking inventory was codified in 369 by a law addressed to the count of the res privata, Florianus. ${ }^{145}$

On the basis of the laws collected in the Theodosian and Justinian Codices, the history of imperial policies for confiscating the churches of heretics can be traced. 
Constitutions usually named the targeted group, the beneficiaries of the confiscated property, and a penalty schedule against those who resisted the constitution's enforcement. What follows is a detailed review of the constitutions, first those addressed to the West, then those to the East.

Imperial Policies in Western Provinces. As for the regions of Italy, North Africa, and Illyricum (when it belonged to the western empire), Valentinian I's, Gratian's, and Valentinian II's policy in 372 and from 377 to 378 divided confiscated ecclesial property. While the public churches themselves were given to the catholic administration, other landholdings associated with the churches, such as revenueproducing land (great houses and estates), were handed over to the fisc. The laws were specifically targeted against the houses and habitations of Manichaeans in Rome, ${ }^{146}$ the churches and great houses and estates of Donatists in North Africa, ${ }^{147}$ and anywhere heretics' altars were located in North Africa. ${ }^{148}$

Honorius made the largest number of confiscations in the western provinces. His initial policy was to have heretics' meeting places benefit the fisc, imperial patrimony, or public use. By the end of 407 , however, he began to have confiscated places given instead to catholic administrators.

As for confiscations that benefited the fisc, in 397, Honorius confiscated Apollinarian ecclesial property in Illyricum. ${ }^{149}$ In 404, Honorius stated that unlawful assemblies could not take place in private dwellings, and a house in which such an assembly occurred would be confiscated. ${ }^{150}$ In 405 , he confiscated Donatist ecclesial property in Italy and North Africa to the fisc. ${ }^{151}$ In 407 , Honorius had the landed estates in Rome, in which Manichaeans, Phrygians, or Priscillianists gathered, transferred to the imperial patrimony; civil officials would be fined either twenty or ten pounds of gold for failure to enforce the law, depending on the office to which they belonged. ${ }^{152}$ In 408 , Honorius had all places of assembly (loca) "of those who dissent from the Catholic priesthood of the church" in Italy and Illyricum appropriated for public use. ${ }^{153}$

Honorius's policy began to shift already at the end of 407, when he had Donatist, Manichaean, Priscillianist, pagan, and Caelicolist buildings in Italy and North Africa vindicated to the churches. ${ }^{154}$ In 412 , he had the churches, conventicles, and landed estates of the Donatists and Circumcellions in North Africa given over to the catholic churches. ${ }^{155}$ In 414 , he had the meeting places of Donatists and heretics in North Africa vindicated to catholic churches, but the penalty fines were to be deposited in the imperial treasury. ${ }^{156}$ Chief tenants of the imperial patrimonies who would allow Donatist practices to take place on the estates would owe a fine equivalent to their rental fee, including emphyteuticaries (lessees of land). Owners of private estates were to replace any chief tenants who permitted Donatist practices to take place there; failure to do so would result in a fine equivalent to the rentals they received. As the case study below shows, once the western regions became regions ruled by non-Roman kings, the tide would 
turn. Former "heretics" would become the catholics, and the catholics would become heretics.

Imperial Policies in Eastern Provinces. In the eastern provinces (including the diocese of Illyricum when it became part of the eastern empire), policies varied from region to region and from emperor to emperor.

As for Theodosius I, he had confiscated churches in Asia handed over to catholic bishops, whereas in the East, confiscations benefited the fisc. In 381, Theodosius I put the churches of Illyricum and Asia in the control of orthodox bishops by issuing two constitutions, both in the wake of the Council of Constantinople. ${ }^{157}$ He named two criteria for determining the orthodoxy of bishops: the use of credal formulas and an alliance with specific bishops known to adhere to the right faith. Theodosius I addressed the rest of his confiscatory legislation to the East. In 381 and 383 , he had churches, estates, and private landholdings of Eunomians and Arians confiscated to the fisc. ${ }^{158}$ His actions in both years targeted Eunomians and Arians; his action of 383 also named Macedonians and Apollinarians. Likewise, in 392, he confiscated all places where "forbidden practices are attempted" to the fisc with a detailed penalty schedule against those guilty of performing illicit services there. ${ }^{159}$ If the owner of the property were unaware of the illegal activity, the chief tenant would be held responsible and owe ten gold pounds if he were freeborn, or otherwise suffer physical torture and deportation. If the illicit practices took place in an imperial or public villa, the chief tenant and procurator each would owe ten gold pounds. Theodosius's application of the fine of ten pounds of gold against heretics in the East would have a long and tortured afterlife in the region of North Africa.

Arcadius largely continued Theodosius I's policy against heretics in the East by placing their meeting places in the hands of catholic administrators (only one constitution he addressed to the East transferred private assembly places to the imperial treasury rather than to the catholic churches), but Arcadius changed the policy in Asia. Instead of giving confiscated properties to the catholic bishops in Asia as Theodosius had done, Arcadius made them fiscal holdings. Arcadius confiscated houses and landed estates in the East, where Eunomians performed services, to the fisc in 398 and $399 .{ }^{160}$ The constitution of 398 named not only Eunomians, but Montanists as well. ${ }^{161}$ In 415 , he confiscated houses and landholdings where Montanist "accursed mysteries" were performed in the East, along with their offertories, and gave them to the catholic churches. ${ }^{162}$ Also in 415 , he had Eunomians' conventicles in their houses or on their landholdings in the East transferred to the imperial treasury. ${ }^{163}$

As for Asia, Arcadius applied the same policy in place for the East. He had all heretics' places in Constantinople confiscated to the fisc in $402 .{ }^{164}$ Arcadius imposed the most severe penalties against violators of his confiscatory laws. The procurator of the landed estate or the steward of the urban house where Eunomian 
rites took place in 398 were to suffer capital punishment; ${ }^{165}$ Arcadius threatened the office of the praetorian prefect in Constantinople with a fine of one hundred pounds of gold if it failed to enforce the law of $402 .{ }^{166}$

Theodosius II issued only one law giving heretics' churches into the hands of the catholics. In 428, he required that the churches taken by heretics from the orthodox in the East be surrendered to the catholic church, including donations and private buildings in which assemblies took place. ${ }^{167} \mathrm{He}$ included a penalty schedule for complicit procurators modeled after the one Theodosius I issued in 392. ${ }^{168}$

In 455, Marcian adopted a policy like that of Valentinian I, Gratian, and Valentinian II in that he confiscated certain properties in Asia and Egypt to the fisc and vindicated other properties to the churches. Marcian legislated that Apollinarians or Eutychites (by which he meant those who do not adhere to definition of faith written at Chalcedon) could not construct churches or monasteries for themselves or congregate in any landholding or monastery. ${ }^{169}$ If they did, the landholding would be confiscated to the fisc but the monastery would fall under the jurisdiction of the church of the city. If they were held without the knowledge of the owner, then the lessee/procurator/manager would be beaten publicly if of low status; if of honorable station, then he would owe ten pounds of gold. If governors or defenders of the city disregarded the constitution, they would owe ten pounds of gold to the fisc and lose their honorable status.

As mentioned above, in 466, Leo closed a loophole. Since sacred things on private estates could pass into the hands of heretics through the transaction of the entire private estate, he passed a law forbidding such transactions. The law emphasizes the same principle of later canons discussed above: that sacred things always remain sacred things. In the case of Leo's law, this meant acknowledging that sacred things would continue to be sacred things even if the larger property on which they were located were confiscated to the fisc:

For whether these estates remain in the hands of orthodox masters or possessors (dominos possessoresve) or become part of Our fisc, it is imperative that the churches and chapels located on them be diligently and carefully restored. For the foresight of Our Serenity leads Us by many ways to this one end: that the temples of the Almighty God, in which the institutions of Our faith endure, shall by continuous attention be preserved through all the ages. ${ }^{170}$

Leo acknowledged a principle that bishops had employed to control churches and oratories on private estates: sacred things located on private property were just as sacred as publicly-available sacred things.

Justinian issued a similar law to the East in 545, but he adopted the opposite policy: instead of confiscating such property to the fisc, he allowed catholic administrators to claim the property. ${ }^{171}$ Justinian allowed churches to claim properties on which owners allowed divine services to take place without the clergy of the bishop (or the properties of the procurators/lessees/emphyteuticaries who 
allowed such services to take place). Churches could also claim property on which there was a church that an orthodox person alienated or bequeathed by emphyteusis, lease, or for any other purpose to a Jew, Samaritan, pagan, Montanist, Arian, or other heretic. If the owner was aware that the lessee or the emphyteuticary was a heretic, the church could also claim the income that would have accrued in the time specified in the contract.

\section{Episcopal Policies on Heretics' Churches}

Bishops could not engage in the imperial act of confiscation, but they did issue regulations of their own to prevent their constituency from attending heretics' churches and to encourage bishops to bring heretic parishes into the catholic fold. As an example of the former type of regulation, a council that met in Laodicea in the last quarter of the fourth century forbade clerics from celebrating divine mysteries and Christians from praying in "the so-called martyria of all the heretics." 172 Canons issued thereafter addressed problems faced in the integration of catholic and formerly heretic ecclesial property. In 418, the Council of Carthage outlined policies for drawing diocesan boundaries in the event that a Donatist bishop joined the catholic communion. ${ }^{173}$ Such boundaries could be changed or contested within a prescriptive period of three years, after which the jurisdictional boundaries were set and deemed unquestionable. ${ }^{174}$ The episcopal assembly encouraged haste in the usurpation of Donatist diocesan territory and constituency whenever a Donatist bishop joined the catholic communion. Such bishops faced a deadline: they were to be zealous in bringing Donatist parishes that had been under their jurisdiction into the catholic fold within six months. ${ }^{175}$ If they failed to do so, any bishop could make such an attempt and receive a jurisdictional reward: the parishes would belong to the successful bishop's jurisdiction. The Council of Toledo, Spain, in 589, on the other hand, maintained existing jurisdictional boundaries even in the face of integration. The synod decided that appropriated heretic churches would belong to the jurisdiction of the bishop of the diocese in which they were located. ${ }^{176}$

At Carthage and in North Africa more generally, bishops exploited the legal apparatus at their disposal to delegitimize Donatist sacred space to the point that one particular legal case became a sticking point from Honorius to Justinian. The stigma of a ten-pound gold fine leveled against the Donatist bishop, Crispinus of Calama, would not be forgotten even one century later.

\section{THE TRIAL OF CRISPINUS OF CALAMA AND THE STIGMA OF TEN POUNDS OF GOLD}

For a century and a half, ten pounds of gold symbolized the delegitimization of ecclesial spaces and administrators in North Africa. The penalty created opportunities for bishops both to shame and patronize other bishops. It all began on 
June 15, 392 when Theodosius I wrote to Tatianus, the praetorian prefect of the East, instructing him that a fine of ten pounds of gold should be applied (1) against whoever permitted the forbidden practices of heretics to take place on a landholding, be it the owner, the chief tenant, or the procurator, and (2) against the cleric who presided over the practice. ${ }^{177}$ As mentioned above, Tatianus was to have the landholding itself confiscated to the fisc, if indeed it was the owner who had permitted the practice to take place. How the law came to be in the East and what sort of afterlife it witnessed there is unknown, but Theodosius I's decision would have a long afterlife in North Africa, enduring even through Justinian's tenure.

Bishops made three traceable efforts to have Theodosius I's law against heretics in the East applied to North Africa. Such bishops endorsed civil regulation of ecclesial property for two purposes: (1) to reclaim or delegitimize rival ecclesial property, and (2) to protect their own ecclesial property from the claims of rivals. Of all the laws issued against heretics, these petitioners chose Theodosius's law that specified a fine of ten pounds of gold so as to shame and patronize rival bishops. ${ }^{178}$ The sum was not negligible. Ten pounds of gold equaled 720 solidi, the cost of building a city martyrion in Edessa in 504/5. ${ }^{179}$ In the end, the bishops succeeded in petitioning Honorius for a law that he issued in 405 against their rivals. ${ }^{180}$

First, Augustine recounts the occasion of a petition, made around $395 / 6{ }^{181}$ In a line-by-line rebuttal of a letter that Petilian, the bishop of Cirta, addressed to his clergy, Augustine mentioned specific cases when individuals, in his perspective, ought to have been fined ten pounds of gold. As an example, he cited an occasion when Bishop Optatus violently took over the administration of a public church. ${ }^{182}$ Augustine said that a petition was made to Seranus, the vicar of Africa, to impose the fine of ten pounds of gold against Optatus, but Augustine admitted that the fine was never paid. ${ }^{183}$ In all likelihood, Seranus denied the request.

Second, in the same passage, Augustine named another bishop against whom he believed a fine of ten pounds of gold should have been imposed: Crispinus of Calama. Around 402, he wrote a letter to Crispinus himself about the situation. ${ }^{184}$ According to Augustine, Crispinus held imperial agricultural lands by emphyteusis (a type of lease) in Mapala. ${ }^{185}$ As a bishop, Crispinus probably acquired the emphyteutic lease to produce revenue for his churches. There, on the imperial estate, Augustine says, Crispinus rebaptized eighty of his tenant farmers. ${ }^{186}$ Since Crispinus engaged in what Augustine counted as a practice forbidden by Theodosius I's law, Augustine argued that Theodosius I's law should apply to Crispinus and that he ought to pay the fine. Augustine expressed his view first with a claim that imperial rules hold force throughout the empire, so even though Theodosius I's law was addressed to the East, it ought to apply in Crispinus's case, too. ${ }^{187}$ Augustine's threatening letter may have served as legal evidence for Crispinus's activities at a trial. ${ }^{188}$

Sometime before $404,{ }^{189}$ Crispinus was tried and fined the penalty of ten pounds of gold. Though the fine was waived, the patronization involved in 
obtaining waivers shamed and subordinated Crispinus. The contentious point of the trial, according to Augustine, was whether Crispinus should be considered a "heretic," so that Theodosius I's law could apply to him. ${ }^{190}$ Crispinus's rival bishop of Calama, Possidius, leveled the case against him, which was heard by the proconsul Septiminus and settled in Possidius's favor. ${ }^{191}$ Possidius, in his capacity as bishop, negotiated (intercedo) for leniency, and Septiminus waived the fine. According to the Life of Augustine, written by the same Possidius of Calama, Crispinus appealed his case to Honorius, who upheld the proconsul's verdict and added the further penalty that the proconsul and his staff should be fined ten pounds of gold, too, for not enforcing their judgment. ${ }^{192}$ Several bishops successfully interceded for the proconsul's and Crispinus's fines to be imperially pardoned. Possidius and other bishops delegitimized Crispinus by successfully petitioning for the implementation of civil regulation against him. The same bishops simultaneously patronized Crispinus by petitioning for the waiver. It is as a result of Crispinus's trial that the fine of ten pounds of gold became in North Africa a stigma and a symbol representing delegitimization and control.

The Council of Carthage in June 404 made the third petition to the emperor against the Donatists. The synod sent the bishops Theasius and Evodius to Emperor Honorius to make a number of requests. The memorandum (commonitorium) with which they were sent begins with an explanation of the circumstances that led to the ensuing requests. ${ }^{193}$ Since rival bishops took over the administration of churches, the synod requested that protection be granted to the public churches both in the cities and in the suburbs. ${ }^{194}$ One specific form of protection that the synod envisioned was that the law of Theodosius I would be confirmed: "that the law, which was promulgated by their father of religious memory, Theodosius, concerning ten pounds of gold against those heretics who ordain or are ordained and also against the proprietors [of properties] where their society is discovered, be ordered in turn to be confirmed." 195 In response, Honorius issued instructions in February 405 to Hadrianus, the praetorian prefect of Italy and Africa. ${ }^{196}$ The law, as transmitted in the excerpts of the Theodosian Codex, does not levy Theodosius I's fine of ten pounds of gold, but nevertheless makes similar provisions. The law states that heresy has been born of schism, so the landholdings where those who rebaptize (thereby practicing "feral sacrilege") are to be confiscated to the fisc. ${ }^{197}$ As for the landholders, if the owner granted permission for the practices to occur, then he or she would be branded with infamy, but if the chief tenant or procurator did, then his or her penalty would be corporal punishment and exile. ${ }^{198}$ Officiating clerics would not owe ten pounds of gold, but would suffer the "penalty of poverty" through the confiscation of all their property. ${ }^{199}$

Despite the fact that Honorius did not name the fine of ten pounds of gold in his instructions to the praetorian prefect Hadrianus, the symbolic status that the penalty attained through the efforts of episcopal petitions and in the trial of Crispinus would not be forgotten. On February 25, 484, the Vandal king Huneric 
issued an edict that deliberately turned the tables and reversed the application of the Roman laws. ${ }^{200}$ Huneric claimed that it was "necessary and very just to twist around against them [imperially supported bishops] what is shown to be contained in those very laws which happen to have been promulgated by the emperors of various times who, with them, had been led into error." 201 The former "catholics," now named "homoousians," could not possess any meeting places or build any churches anywhere; if any should be built, they would be confiscated to the fisc. Their current churches were to be vindicated to the now "orthodox" (the administrators endorsed by the king). The notorious penalty of ten pounds of gold applied to those who ordained heretic clergy and those who allowed themselves to be ordained. ${ }^{202}$

On August 1, 535, the tables turned yet again with Justinian's conquest of North Africa. Justinian returned all churches and ecclesial possessions to the orthodox, identified as Reparatus of Carthage and his synod. ${ }^{203}$ The penalty of ten pounds of gold would be applied to any violators. Arians, Donatists, Jews, and any other nonorthodox were "excluded altogether from services, and from churches" and were not permitted to possess "conventicles." 204

In the East, on the other hand, where the fine had first been levied against heretics in 392, Justinian pursued the prosecutors. He addressed Edict 2 to the praetorian prefect of the East, John, probably before 535. The edict forbids the abuse of laws that impose fines on heretics and demands the arrest of, and the imposition of fines on, those who "have gone out to various provinces to search out those who have abandoned themselves to the error of the heretics [... ] and have taken a very great deal of money from them by way of sportulae [payments or fees]." 205 The fate of the fine in the East reinforces its symbolic status. Because individuals in the East exploited the law so as to exact enormous capital from heretics, Justinian issued an edict to curb such exploitation.

In North Africa, on the other hand, where the imposition of the fine did not in fact result in financial capital, but rather a capital of status and control, the penalty had a different history. Through episcopal petitions for civil regulation, what began in the East became in North Africa a distinct symbol of the dividing line between rival res sacrae and administrators.

Jurists and bishops imagined churches as sacred things that the right bishops produced and the right bishops administrated. Jurists decided which bishops were imperially-recognized bishops and therefore which sacred places were imperially sanctioned sacred places. Both jurists and bishops masked their control by treating the legal principles as unquestionable givens.

Roman jurists of the first three centuries conceived of res sacrae as things ritually consecrated to deities. Justinian would rewrite the legal definition with explicit reference to the Christian deity, Christian ritual practice, and Christian ritual agents, but emperors, jurists, and bishops from Constantine onward had already brought Christian temples under the control of the legal imagination about 
res sacrae. To those places that "heretics" considered churches, jurists and imperially supported bishops would ascribe no sanctity. The procedure of confiscation delegitimized such places and sometimes used them to profit the jurisdictions of legally supported bishops.

Through imperially recognized rituals of consecration, churches attained the legal status of "sacred thing." This legal status came with a significant benefit: churches were thereby recognized as divinely protected. The next chapter analyzes the jurisdic pedagogy that undergirded this corollary to the definition of res sacrae and the legal mechanisms by which jurists and bishops produced and applied such a notion of protection. The corollary protected res sacrae from loss of assets and promoted their affluence. 